Originally appeared in: Kadmos XXVII,2 (1989), 146-155.

\title{
The syntax of the New Phrygian inscription No. 88
}

\author{
ALEXANDER LUBOTSKY
}

$\S 1$. For the interpretation of Phrygian inscriptions we have at our disposal two sources of syntactic information: syntactic constructions attested in Phrygian and peculiarities of the Greek language of the "Phrygian" area of A sia M inor. In the present article I would like to demonstrate how we can use this information for the analysis of Phrygian inscriptions, taking as an example inscription No. 88, which was published for the first time by Calder (1928: 216f). This inscription contains a Greek and a Phrygian part:

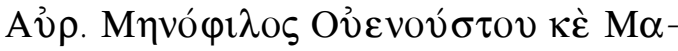

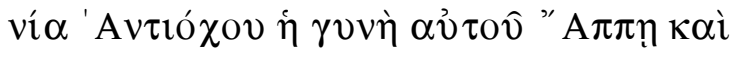

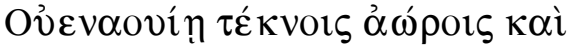

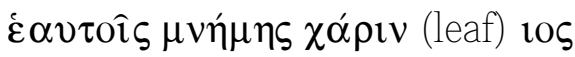

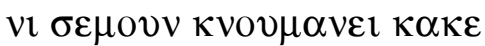

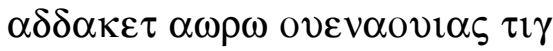
$\gamma \varepsilon \gamma \alpha \rho \imath \tau \mu \varepsilon v 0<\zeta>\varepsilon \imath \tau 0 v \pi \circ 0 \rho$ ov $\alpha v \alpha-$

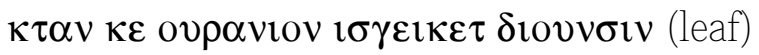

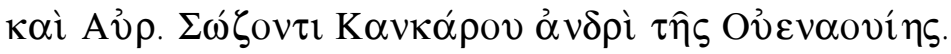

A s usual, the Greek part contains an epitaph, from which we learn that the grave has been made by $M$ ēnophilos and his wife $M$ ania for their prematurely deceased children, Appē and Ouenaouia, and for themselves. The message at the end of the inscription, concerning the burial of Sōzōn, the husband of Ouenaouia, "may be a later addition" (Calder 1928: 217).

The Phrygian part constitutes a malediction against the violator of the tomb. Its protasis,

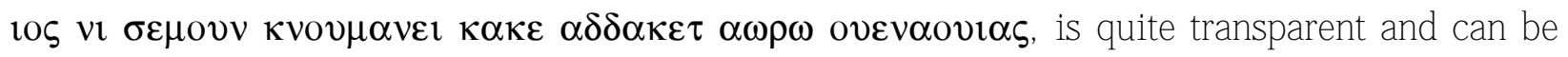
translated 'whoever brings harm to this premature tomb of V enavia', $\alpha \omega \rho \omega$ standing for $\mathrm{Gr}$.

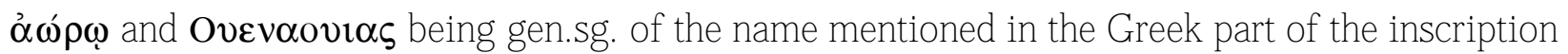
(cf. Haas 1966: 94). ${ }^{1}$

The rest of the inscription, viz.

\footnotetext{
${ }^{1} \mathrm{H}$ aas translates 'wer diesem frühzeitigen Grabe der Ouen<a>ouia etwas Ü bles zufügt' (the omitted -a- in the name Ouenaouia is a misprint). The only correction which must be made to Haas' analysis regards the interpretation of $\tau \imath$. Haas takes it as a pronomen indefinitum $* k$ wid, belonging to $\kappa \alpha \kappa \varepsilon$, but, as B rixhe has shown (1978a: $8 \mathrm{ff}$.), $\tau \imath(\tau)$ is a particle, always making part of the apodosis and standing immediately before the participle / adjective of the predicate. Haas 1976a: 77 tacitly corrected the translation himself: "W er diesem allzufrühen Grabe der Venavia

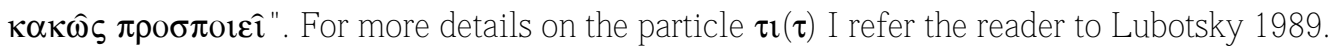




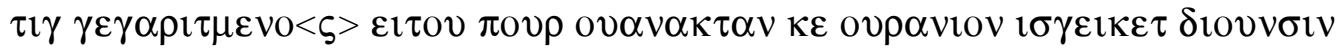

is much more problematic, although some elements of this passage are easily identifiable. The first three words, $\tau \imath \gamma \gamma \varepsilon \gamma \alpha \rho \imath \tau \mu \varepsilon v 0<\varsigma>\varepsilon \imath \tau o v$, must constitute a curse 'let him be condemned' uel

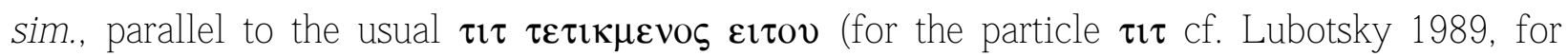

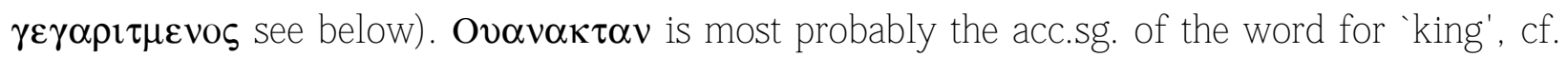
Old Phrygian (OPhr.) nom.sg. (modro)vanak (M-04), dat.sg. vanaktey (M-01a), whereas oupaviov is likely to be the acc.sg. of an adjective, borrowed from G reek ov póvios 'heavenly'.

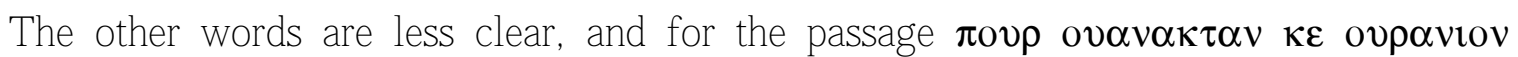

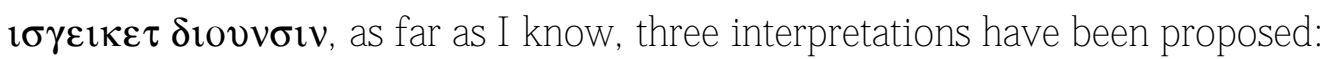

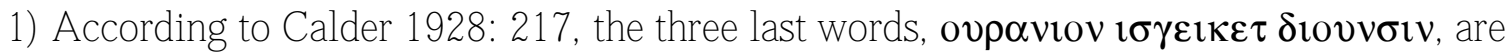

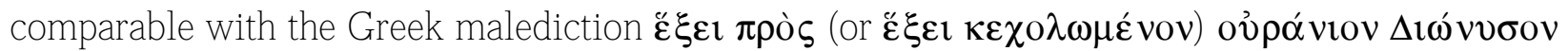
(in ov $\alpha v \alpha \kappa \tau \alpha v$ Calder saw a name). Calder's analysis was accepted by Gusmani (1958: 902),

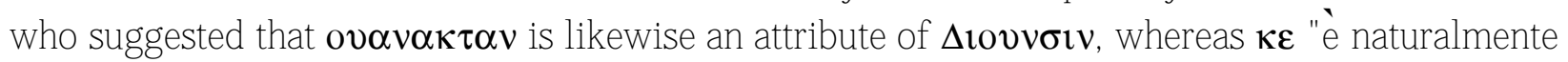
I'enclitica e serve da elemento coordinatore con quello che precede".

2) Haas (1966: 109) assumed that the malediction formula ends after the curse $\tau \imath \gamma$

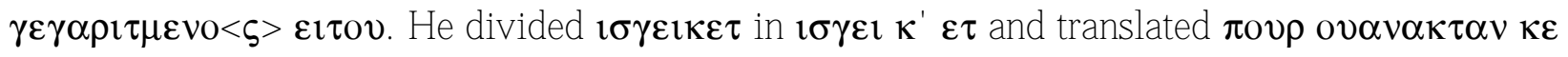

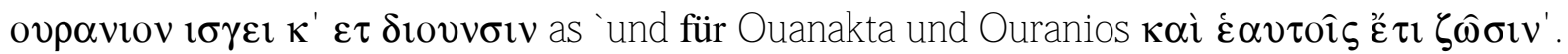

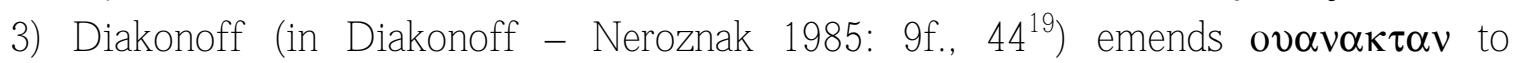

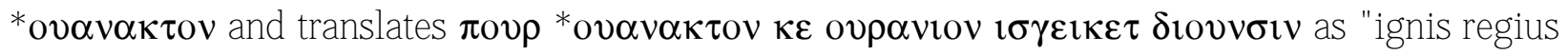
caelestisque incendat ex caelis" (lit. excendat, cf. OSlav. izŭ-ž̆go "I shall burn [it] out"), "the royal and celestial fire, descending from heaven, (shall) burn (him)" (p. 10).

In order to assess the probability of these proposals, it is necessary to analyze the syntactic behaviour of two key-words of this inscription, viz. $\gamma \varepsilon \gamma \alpha \rho \imath \tau \mu \varepsilon v o \varsigma$ and $\kappa \varepsilon$.

§ 2. $\gamma \varepsilon \gamma \alpha \rho \imath \tau \mu \varepsilon v o \varsigma$ is nom.sg. of a perf.part.med. Already Calder (1926: 24) drew

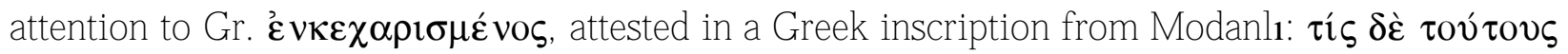

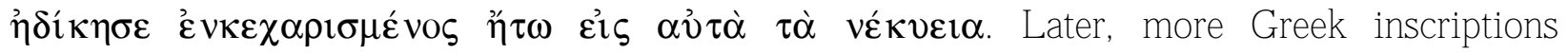

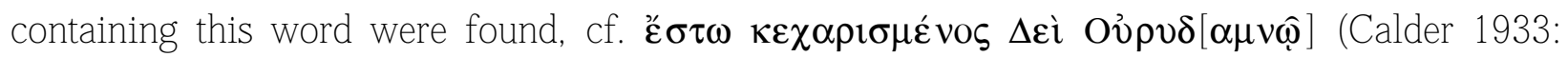

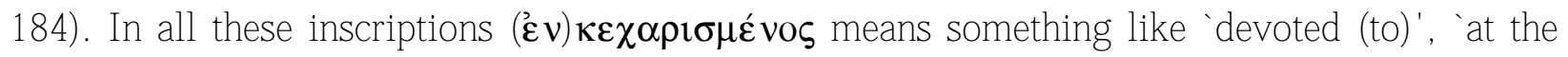
mercy of'.

Calder proposed to see in these formulae the Greek rendering of the Phrygian expression with $\gamma \varepsilon \gamma \alpha \rho \imath \tau \mu \varepsilon v o \varsigma$ and asked: "Is $\gamma \varepsilon \gamma \alpha \rho \imath \tau \mu \varepsilon v o \varsigma$ simply $\kappa \varepsilon \chi \alpha \rho \imath \sigma \mu \varepsilon$ vo $v$ borrowed and dressed in a Phrygian disguise, or is it a genuine Phrygian word?" I believe that borrowing from Greek is hardly probable, as the difference in form and meaning is too considerable for a loan. Note that Gr. $\chi$ appears as Phr. $\kappa$ in кopos, which is attested in the protasis of inscription 92:

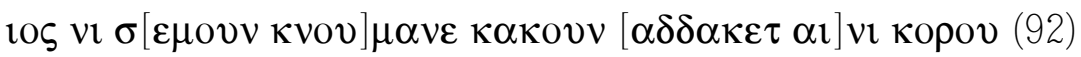

'whoever brings harm to this grave or to the אopos' (B rixhe 1978b: $3^{12}$, Calder 1933: 116) and 
which seems to be a recent loan from Greek $\chi \omega \hat{\omega}$ pos 'place' (Brixhe 1983: 127). Therefore, we would expect $\kappa \varepsilon \chi \alpha \rho ı \sigma \mu \varepsilon v$ vo to be reflected in Phrygian as ${ }^{*} \kappa \varepsilon \kappa \kappa \alpha \rho \imath \sigma \mu \varepsilon v o \varsigma$. The answer to Calder's question must therefore be that $\gamma \varepsilon \gamma \alpha \rho \imath \tau \mu \varepsilon v o \varsigma$ is a genuine Phrygian word.

I believe that the shift of meaning of $\kappa \varepsilon \chi \alpha p ı \sigma \mu \varepsilon$ vos in the Greek inscriptions of Phrygia ('devoted to' instead of the usual 'agreeable') must be due to the influence of $\gamma \varepsilon \gamma \alpha \rho \imath \tau \mu \varepsilon v o s$, which presumably had both these meanings. In other words, when Phrygians composed malediction formulae in Greek, they used the usual Greek equivalent of $\gamma \varepsilon \gamma \alpha \rho \imath \tau \mu \varepsilon v o s$, viz. $\kappa \varepsilon \chi \alpha \rho ı \mu \varepsilon \dot{v}$ vos. A similar point of view has already been expressed by Haas $\left(1951: 27^{10}\right)$ and Heubeck (1959: 15). The consequence of this view is that the syntax of Greek inscriptions with $\kappa \varepsilon \chi \alpha \rho \iota \sigma \mu \varepsilon$ vo is based on the Phrygian formulae and can provide us with important information (see below).

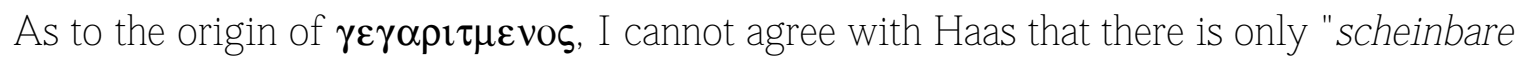
etymologische Entsprechung" between $\gamma \varepsilon \gamma \alpha \rho \imath \tau \mu \varepsilon v o \varsigma$ and $\kappa \varepsilon \chi \alpha \rho \imath \sigma \mu \varepsilon \dot{v o \varsigma}$ (1966: 95). ${ }^{2} \mathrm{Gr}$.

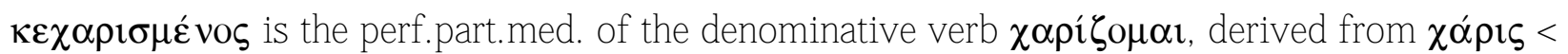
PIE $* g^{h} r H-i-$, an original i-stem (cf. acc.sg. $\left.\chi \alpha^{\prime} \rho \imath v, \chi \alpha \rho i ́-\varepsilon 1 \varsigma, \chi \alpha \rho \imath-\delta \omega^{\prime} \tau \eta \varsigma\right)$ ), which has been enlarged to a t-stem (gen.sg. $\chi \alpha \dot{\rho} \rho \tau \tau_{\text {, }}$, etc.). It seems plausible to identify the root of the 149 Phrygian verb, - $\gamma \alpha \rho \imath \tau-$, with Gr. $\chi \alpha$ ó $\tau$ - (for the development of vocalic resonants see below, $\S 4.1)$, which would indicate that the t-suffix is old and is a common innovation of both languages. Moreover, this analysis provides another proof that Phrygian is a centum language

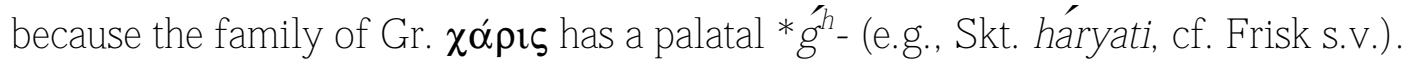

Let us now look at the actual occurrences of $\gamma \varepsilon \gamma \alpha \rho \imath \tau \mu \varepsilon v o s$. A part from our inscription, it occurs only in one context ( $\gamma \varepsilon \gamma \alpha \rho i \tau \mu \varepsilon v o s$ has also been restored in 64 and 79, but the context there is unclear), viz. the malediction formula

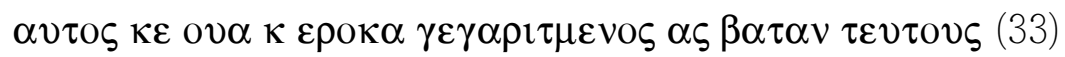

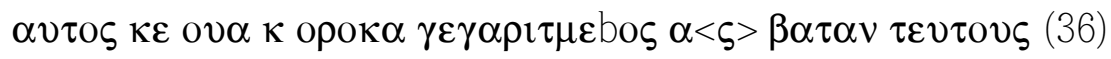

Although the exact meaning of $\varepsilon /$ opok $\alpha$ is unknown, the syntax of the beginning of the mal ediction is clear: 'and he himself and his (ov $\alpha$ ) $\varepsilon /$ орок $\alpha$ (progeny / family ?)'. We have seen

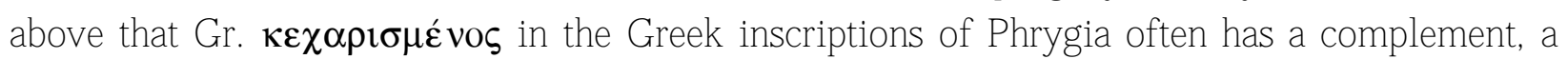
deity, to whom the violator of the grave will be devoted, and that this use was most probably borrowed from Phrygian. This implies that we must look for the name of a deity in $\alpha \varsigma \beta \alpha \tau \alpha \nu$

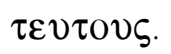

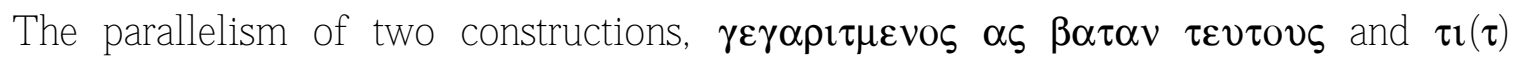

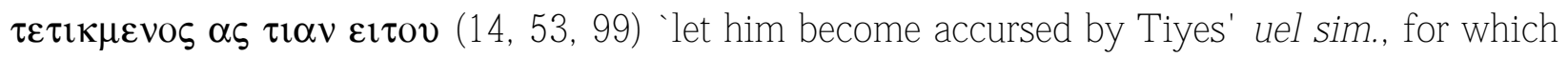
see L ubotsky 1989, suggests that $\alpha \varsigma \beta \alpha \tau \alpha v$ must be analysed as the preposition $\alpha \varsigma+$ acc.sg. of a

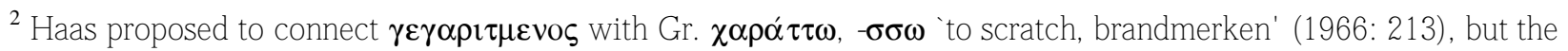
vocalism of the Greek and Phrygian words seems to be unreconcilable, and, moreover, the comparison is semantically weak, cf. Heubeck 1987: 74.
} 
deity, whereas $\tau \varepsilon v \tau$ ov $\varsigma$ is a verbal form (so al ready Gusmani 1958: 903). As the acc. $\beta \alpha \tau \alpha \nu$ can belong either to an $\bar{a}$-stem, or to a consonant stem, it is tempting to take $\beta \alpha \tau \alpha v$ as acc.sg. of a t-

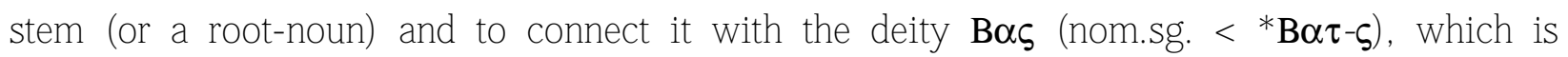
mentioned among other deities in 48 (Mı

$\S 3$. Essential for the syntactical analysis of the inscription is the position of the conjunction particle $\kappa \varepsilon$. Recently, Brixhe discussed the syntax of Phrygian $\kappa \varepsilon$ (1978b: 1ff.), and his conclusions can be summarized as follows:

1. When used as a word conjunction, $\kappa \varepsilon$ appears either after each member ( $X \kappa \varepsilon Y \kappa \varepsilon$ : $\delta \varepsilon \omega \varsigma \kappa \varepsilon \zeta \varepsilon \mu \varepsilon \lambda \omega \varsigma \kappa \varepsilon)$, or after the second word only (X Y $\kappa \varepsilon: \delta \varepsilon \omega \varsigma \zeta \varepsilon \mu \varepsilon \lambda \omega \varsigma \kappa \varepsilon)$.

2.1. When used as a sentence conjunction, $\kappa \varepsilon$ appears after the first word of the second clause. The clear cases are:

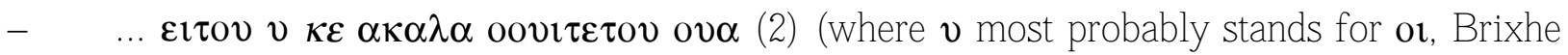
1979: 192),

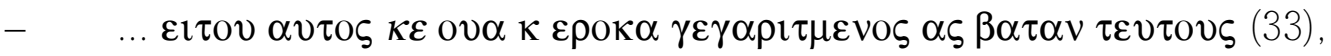

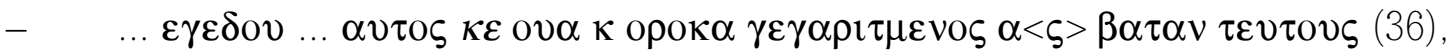

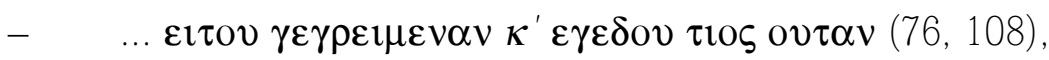

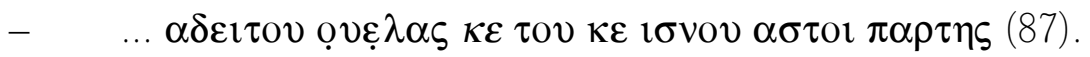

2.2. B rixhe does not separately discuss those cases where the second clause starts with a preposition. Here we must distinguish between combinations of a preposition + a clitic and combinations of a preposition + a noun. It seems that in the former case $\kappa \varepsilon$ appears after the first word, too, cf.:

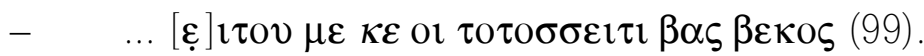

I therefore believe that $\alpha \kappa \kappa \varepsilon o l$, attested in

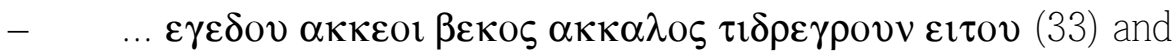

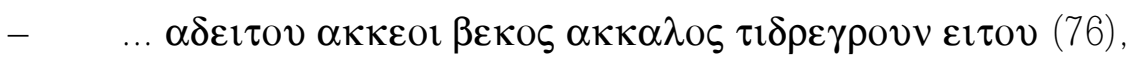

must similarly be analysed as the preposition $\alpha \delta+\kappa \varepsilon+$ pron. or (contra Haas 1966: 84 and B rixhe 1978b: 2, according to whom $\alpha \kappa \kappa \varepsilon$ is of the same origin and function as $L$ at. atque).

On the other hand, in the case of combinations of a preposition + a noun $\kappa \varepsilon$ appears after the noun:

\footnotetext{
${ }^{3}$ The name of $B$ as also occurs in formulae with $\beta \varepsilon \kappa o \varsigma$ 'bread'. The identical apodoseis of 86 ( $\beta \alpha[\varsigma]$ tot $\beta \varepsilon \kappa o \varsigma \mu \varepsilon$

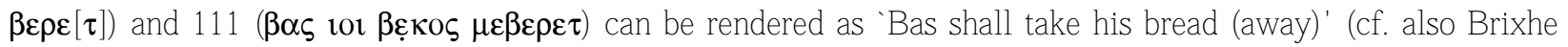
1979: 189, who takes бion as a pronoun and translates: "que X lui refuse le pain"). I assume that the apodosis of 99

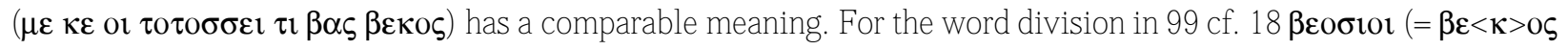

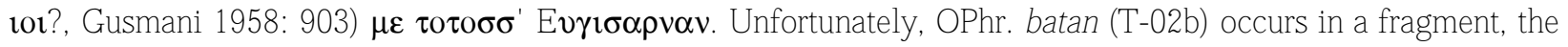
context of which is unclear.
} 
- $\quad . . . \varepsilon \varepsilon \tau 0[v] \alpha \tau \tau \imath \eta \kappa \varepsilon \alpha \delta \varepsilon \imath \tau O v(39)$,

- $\quad . . . \mu \varepsilon \beta \varepsilon \rho \varepsilon[\tau] \alpha \tau \tau \imath \eta \kappa \varepsilon \tau \imath \tau \varepsilon \tau \imath \kappa \mu[\varepsilon] \operatorname{vo\zeta } \varepsilon \imath \tau O v(86)$.

(For the analysis of the malediction formulae with $\alpha \tau \tau \imath \eta$ and $\alpha \varsigma \tau \imath \alpha \nu$ see L ubotsky 1989).

It follows that the interpretation of Haas (1966: 109), who divided

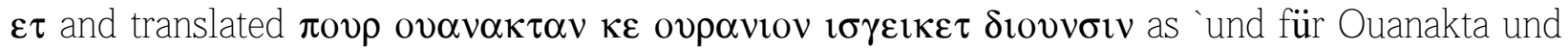

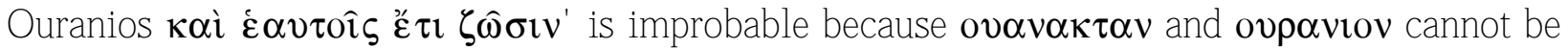
coordinated nouns connected by $\kappa \varepsilon$. The same syntactic objection (among many others) holds for the analysis of Diakonoff (Diakonoff - Neroznak 1985: 9f. and $44^{19}$ ), who emends ov $\alpha v \alpha \kappa \tau \alpha v$ to * ov $\alpha v \alpha \kappa \tau$ ov and translates the sentence as 'ignis regius caelistisque incendat ex caelis'.

In taking $\kappa \varepsilon$ either as a word conjunction or as a sentence conjunction, we have two

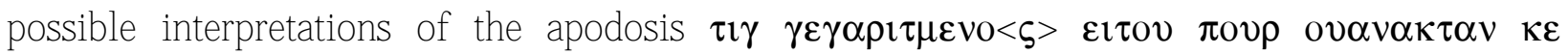

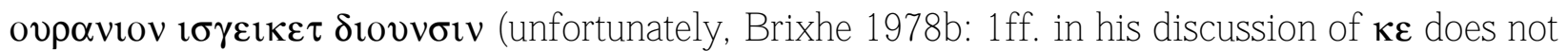
mention inscription 88 and therefore does not express his position on the matter):

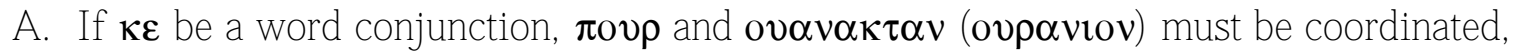
both being the direct object of $\gamma \varepsilon \gamma \alpha \rho \imath \tau \mu \varepsilon v o s$. However, this analysis presupposes a transitive

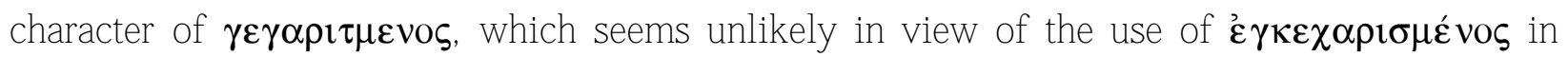
Greek inscriptions (v. supra).

B. If $\kappa \varepsilon$ be a sentence conjunction, either $\pi$ ov $\rho$ belongs to the preceding clause (the

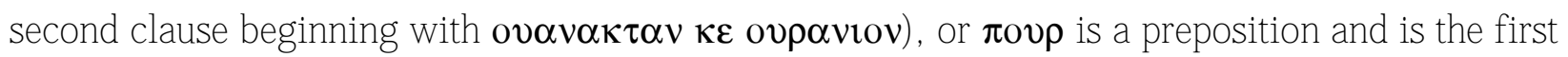
word of the clause. The former al ternative meets the same objection as in A, so that we arrive at the following syntactic analysis:

apodosis 1: $\tau \imath \gamma \gamma \varepsilon \gamma \alpha \rho \imath \tau \mu \varepsilon v<\varsigma>\varepsilon \imath \tau o v$ 'let him be devoted';

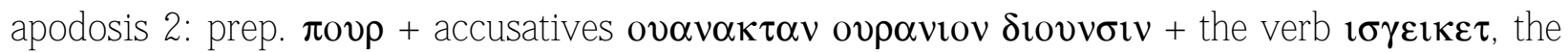
two apodoseis being connected by $\kappa \varepsilon$ in the position after the noun, which is in accordance with rule 2.2 above.

$\S 4$. In other words, we must return to the interpretation given by Calder and Gusmani

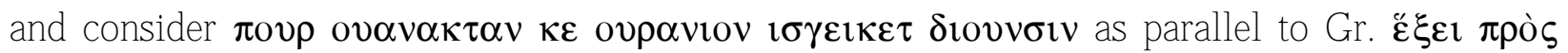
oủ $\alpha$ v́viov $\Delta$ tóvvoov. L et us now discuss the three remaining words.

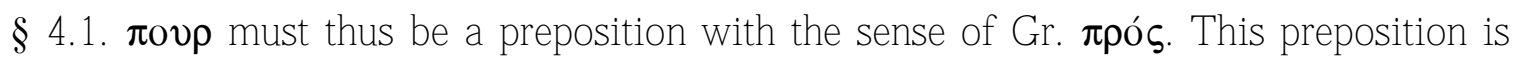
probably also found in OPhr. inscription W-05b, which can be read ]ạnst[...][e]daespormatẹr[ and analyzed as Obj. (...an), Subj. (NPr. St...), V erb ([e]daes 'made, dedicated'), por 'for', acc.sg. mater[an] or dat.sg. mater[ey] 'M other' (cf. B rixhe-L ejeune 1984: 49). W hat was the proto-form of this preposition? Gusmani 1958: 902 reconstructed *pōr (por) and compared Lat. prō, Skt. pra, etc., but *pōr is nowhere attested, whereas * por in L at. porrō reflects rather *pr- (the same origin may be proposed for $\mathrm{Gr}$. $\pi$ ó $\rho \rho \omega$, $\pi$ ó $\rho \omega \omega$ with A eolian vocalization). Therefore, we must assume 
that OPhr. por, N Phr. $\pi$ ovp reflects PIE * pr (cf. Gr. $\pi \alpha \dot{\rho} \rho$, Goth. faur, etc.).

This reconstruction furnishes the first certain example of a reflex of PIE *r in Phrygian. There seems to be a communis opinio that PIE *r and *! yield Phrygian ar, al (Haas 1966: 205, Bajun - Orël 1986: 209, Diakonoff - Neroznak 1985: 5), but the material presented by Haas is unreliable, while the Soviet scholars do not adduce any evidence in favour of this development. Moreover, reconsidering the attestations of Phr. -ar-, we see that they all may have another origin:

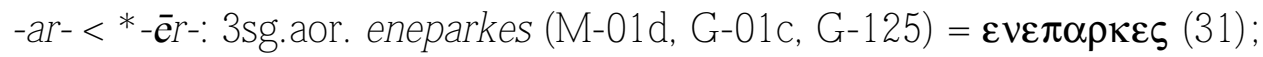

nom.sg. matar $=\mu \alpha \tau \alpha \rho(18), \alpha v \alpha \rho$ (15);

3sg.pf. $\delta \alpha \kappa \alpha \rho(18), 3 p l . ~ \delta \alpha \kappa \alpha \rho \varepsilon v(98) ;$

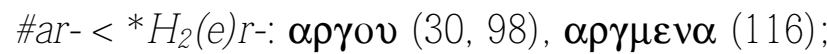

Personal names: K avarmoyos* (B-01), A gartioi (G-02);

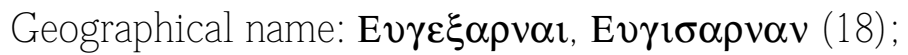

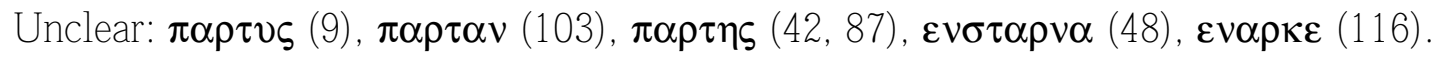

The only form where -ar- seems to reflect syllabic $r$ is $\gamma \varepsilon \gamma \alpha \rho \imath \tau \mu \varepsilon v o s<*_{-} g^{h}$ rHitdiscussed above (\$2), but reflexes of syllabic resonants before a laryngeal may differ from those in other positions (cf. Skt. -ir-/-ur- $<* C r H V$ vs. $-r-<* C r C$ ).

On the other hand, it is difficult to find further evidence in favor of the development PIE $*_{r}$, ! > Phr. or/ur, ol/ul because Phr. or/ol may also reflect PIE *or/ol. We have the following material:

1. The ending of 3sg.med. $\alpha \delta \delta \alpha \kappa \varepsilon \tau o \rho, \alpha \beta \beta \varepsilon \rho \varepsilon \tau \circ \rho$, if <*-tr;

2. OPhr. nom.sg. sakor (G-105, cf. Lubotsky 1988: 21), tekmor (P-04) may reflect*-r, although the ending *-ōr is also possible;

3. There are several cases of Phr. ol which may reflect syllabic resonants: OPhr. isvolkay

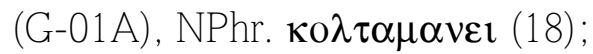

4. Moreover, as I have tried to demonstrate elsewhere (1988: 23), Phr. $0>\mathrm{u} /$ _i , li. Some of these combinations ury, uly may likewise reflect syllabic resonants, cf. esuryoyoy (M01f), voineiosuriienoisku... (G-145), kuliyạ[... (G-101), kụliyas (G-127).

$\S$ 4.2. A ccording to Calder's analysis, $\sigma \gamma \varepsilon \varepsilon 1 \kappa \varepsilon \tau$ must be a verb parallel to $\mathrm{Gr} .{ }^{\natural} \xi \varepsilon{ }^{4}{ }^{4}$ It is tempting to see in - $\sigma \gamma$ - the zero-grade of the root of $\mathrm{Gr}$. $\varepsilon^{\prime} \chi \omega$. The initial $\mathrm{\imath -}$ may be prothetic because "Phrygian" Greek regularly shows prothetic i- before word-initial SC-clusters (cf. Dressler

\footnotetext{
${ }^{4} \mathrm{~K}$ retschmer (1932: 66) considered $\sigma \gamma \varepsilon 1 \kappa \varepsilon \tau$ a loan from Gr. है $\sigma \chi \eta \kappa \varepsilon$, but this explanation cannot account for the Phrygian - $\gamma$ - (see above on Phr. $\kappa$ for Gr. $\chi$ in loan-words) and is therefore improbable. On the other hand, our

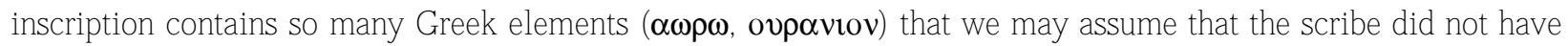
sufficient command of Phrygian. It seems then conceivable that $1 \sigma \gamma \varepsilon \iota \kappa \varepsilon \tau \tau$ contains the productive G reek element - $\kappa-$

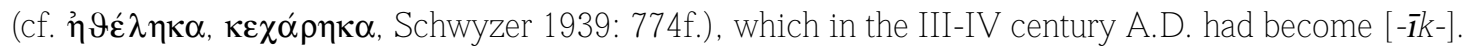


1965: 96ff. and Brixhe 1984: 115f.). The ending is the same as in 3sg.fut./subj. $\alpha \delta \delta \alpha \kappa \varepsilon \tau$, which also shows a secondary $-\kappa$ - taken from the perfect. The only problem is the enlargement - $\varepsilon$ -

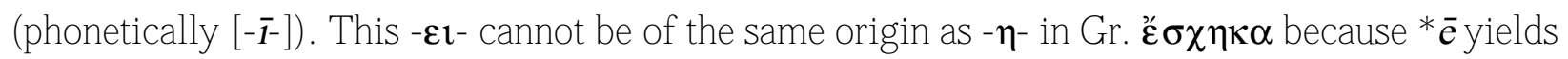
Phr. a, but as the Greek - $\eta$ - is secondary and as we know so little about the Phrygian verbal morphology, we may assume for the time being that Phrygian used a secondary enlargement - $\varepsilon \iota^{-}$ where Greek used - $\eta$ - (cf. also fn. 4).

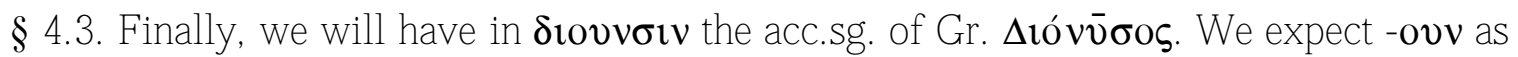

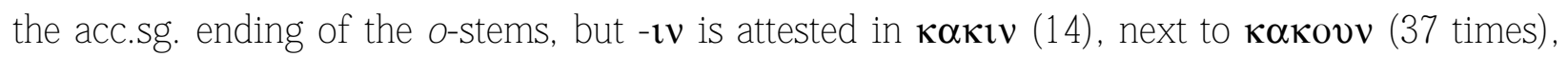

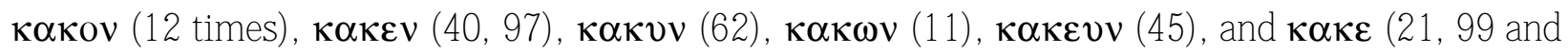
in our inscription 88), cf. also $\sigma \varepsilon \mu \mathrm{\iota v}(76,100)$ instead of $\sigma \varepsilon \mu \mathrm{ovv}$ (passim). Gusmani (1958: 902) explains the aberrant form $\delta$ iovvouv by a syncope, followed by the raising of - 0 - to - $\mathrm{u}$ - before a nasal, but we may also suggest a scribal error, which led to the spelling $\delta$ rovvorv, instead of

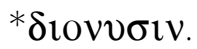

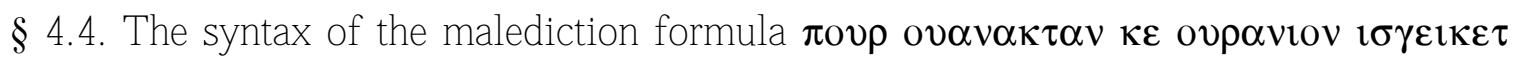
$\delta i o v v \sigma i v$, with the nominal syntagm interrupted by a verb, may appear aberrant, but this syntax is not without parallels, cf.

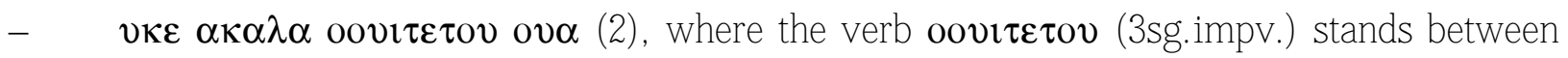
the coreferential $\alpha \kappa \alpha \lambda \alpha$ and ov $\alpha$ (<*su a a 'his own');

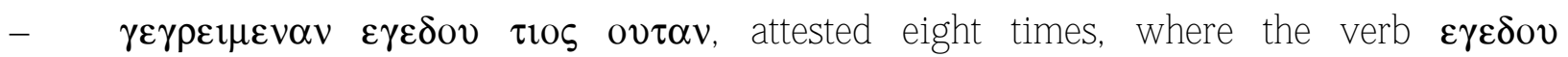
(3sg.impv.middle) interrupts the nominal syntagm, consisting of the coreferential $\gamma \varepsilon \gamma \rho \varepsilon \mu \mu \varepsilon v \alpha \nu$ and ov $\tau \alpha v$ plus gen.sg. $\tau 10 \varsigma$ 'the established punishment of (god) Tiyes' uel sim. (cf. Haas 1966:

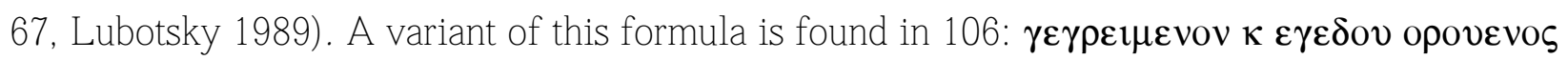
ovนov.

\section{$\S 5$. Conclusions}

1). The NPhr. inscription N o. 88 represents a malediction against the violator of the tomb

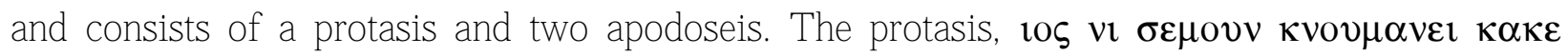

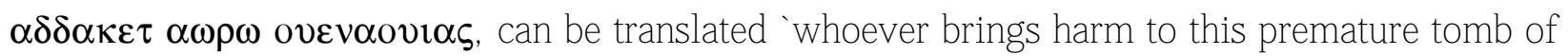

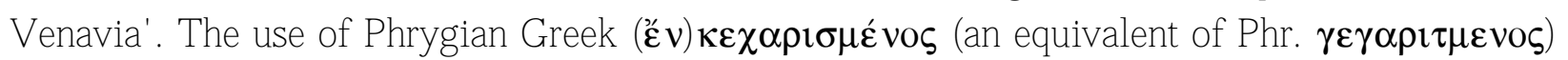
and the syntax of Phr. $\kappa \varepsilon$ show that the rest of the inscription must be divided into two apodoseis, which is in accordance with the interpretation of Calder (1928: 217) and Gusmani (1958: 902):

- $\quad \tau \imath \gamma \gamma \varepsilon \gamma \alpha \rho \imath \tau \mu \varepsilon v o<\varsigma>\varepsilon \imath \tau o v$ 'let him become cursed/devoted' and

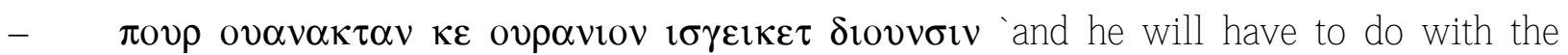

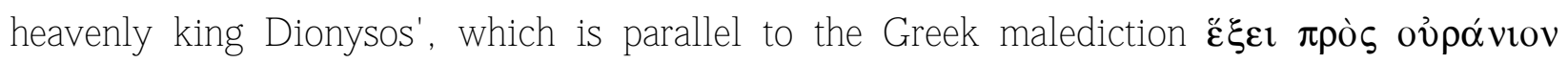
$\Delta$ tóvvoov. 
2). The root of Phr. $\gamma \varepsilon \gamma \alpha \rho \imath \tau \mu \varepsilon v o \varsigma$ may be identified with Gr. $\chi \alpha \alpha^{\prime} \tau \tau-<* g^{h} r H-i-t-$, which would indicate that the t-stem of this word is a common innovation of Greek and Phrygian. M oreover, this analysis provides another proof that Phrygian is a centum language.

3). The sentence conjunction $\kappa \varepsilon$ mostly stands after the first word of the second clause, except if the second clause starts with a combination of a preposition + a noun. In the latter case $\kappa \varepsilon$ stands after the noun.

4). The word $\pi$ ov $\rho$ appears to be a preposition going back to PIE *pr, which makes it likely that the Phrygian reflex of PIE vocalic resonants is or/ur, ol/ul.

\section{Postscript}

In a recent publication, L.S. Bajun and V.È. Orël ("Jazyk frigijskix nadpisej kak istori\%skij isto\%ik II", Vestnik drevnej istorii, 1988/4, p. 132-167) propose the following translation of the NPhr. inscription No. 88 (p. 152f.): "K to ètoj preždevremennoj grobnice V enavii zlo pri\%nit, (tot) da budet prokljat. Ogon' (da) soxranit nebesnogo carja sredi (ili: dlja) nebesnyx (božestv)" ("He who brings harm to this premature tomb of $V$ enavia, let him be cursed. $M$ ay the fire keep the heavenly king among (or: for) the heavenly (deities)".) In my opinion, the second sentence does not make any sense and is misplaced in a curse. M oreover, their assumtion that $\kappa \varepsilon$ was used in the construction noun + attribute is improbable.

\section{References}

Bajun, L.S. - Orël, V.Ė. 1986: Review of B rixhe-Lejeune 1984. Vestnik drevnej istorii 1986/3, 202-210. Brixhe, Cl. 1978a: Études neo-phrygiennes I, V erbum 1,1, 3-21.

Brixhe, Cl.1978b: Études neo-phrygiennes II, V erbum 1,2, 1-22.

B rixhe, Cl.1979: Études neo-phrygiennes III, V erbum 2,2, 177-192.

Brixhe, Cl.1983: Épigraphie et grammaire du phrygien: état présent et perspectives. Le lingue indoeuropee di frammentaria attestazione / Die indogermanischen Restsprachen, ed. by E.V ineis. Pisa, 109-131.

B rixhe, $\mathrm{Cl} .1984$ : Essai sur le grec anatolien au début de notre ère. Nancy.

Brixhe, Cl. - Lejeune, M. 1984: Corpus des inscriptions paléo-phrygiennes. 2 vols. Paris.

Calder, W.M. 1926: Corpus inscriptionum neo-phrygiarum III. JHSt. 46, 22-28.

Calder, W.M. 1928: M onumenta A siae M inoris Antiqua I. M anchester.

Calder, W.M. 1933: M onumenta A siae M inoris A ntiqua IV. M anchester.

Diakonoff, I.M . - Neroznak, V.P. 1985: Phrygian. N ew Y ork.

Dressler, W. 1965: i-Prothese vor s impurum in K leinasien (und in Vulgärlatein). Balkansko Ezikoznanie 9,2, 93-100.

Gusmani, R. 1958: Studi sull'antico frigio, RIL 92, 835-69, and Le iscrizioni dell'antico frigio, RIL 92, 870-903. 
Haas, 0. 1951: Zur Deutung der phrygischen Inschriften, RHA XI (f.53, 1-30.

Haas, 0.1966: Die Phrygischen Sprachdenkmäler, Sofia.

Haas, 0.1976a: Die Sprache der spätphrygischen Inschriften I. B alkansko Ezikoznanie XIX/3, 49-82.

Haas, 0.1976b: Die Sprache der spätphrygischen Inschriften II. B alkansko Ezikoznanie XIX/4, 53-71.

Heubeck, A. 1959: Bemerkungen zu den neuphrygischen Fluchformeln. IF 64, 13-25.

Heubeck, A. 1987: Phrygiaka I-III. K Z 100, 70-85.

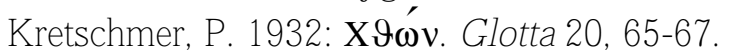

L aminger-Pascher, G. 1984: B eiträge zu den griechischen Inschriften $L$ ycaoniens. Wien.

L ubotsky, A. 1988: The Old Phrygian A reyastis-inscription. Kadmos 27/1, 9-26.

L ubotsky, A.1989: New Phrygian $\varepsilon \tau \imath$ and $\tau$. Kadmos 28, 79-88.

Schwyzer, E. 1939: Griechische Grammatik. B and I. M ünchen. 